\title{
Public Policies in Favelas and the Production of Urban Inequalities in Rio de Janeiro
}

\author{
By Neiva Vieira Da Cunha
}

Introduction- In the past three decades, we have witnessed the worldwide development of new economic dynamics that have intensified the most perverse and harmful effects of globalization processes. The global economy has increasingly produced intense social vulnerability and has driven a large number of people out of the center of the economic and social order (Sassen, 2016). This economic model responds to a logic of financialization of all domains of social life, imposed by different political choices and decisions that result in the degradation of working conditions and the increase of precariousness and insecurity throughout the world (Harvey, 1985). These consequences are not new and have already been described and analyzed by authors such as Serge Paugam (1991), Robert Castel (1995), and Didier Fassin (1996), among others. However, as Saskia Sassen (2016) points out, in a broader sense, this logic of financialization and production of new inequalities underway in the contemporary world can be seen as a more profound systemic underlying tendency that articulates realities that unite us. They often seem disconnected, and their modes of action, which can be characterized by their complexity, may include different dynamics and even coexist with economic growth.

GJHSS-E Classification: FOR Code: 160510

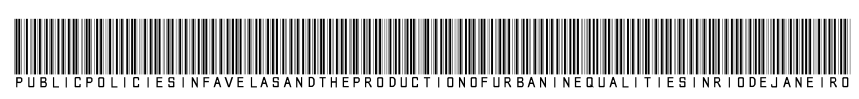

Strictly as per the compliance and regulations of:

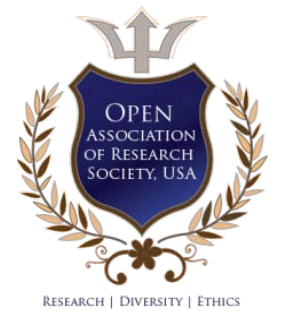

(C) 2020. Neiva Vieira Da Cunha. This is a research/review paper, distributed under the terms of the Creative Commons AttributionNoncommercial 3.0 Unported License http://creativecommons.org/licenses/by-nc/3.0/), permitting all non-commercial use, distribution, and reproduction in any medium, provided the original work is properly cited. 


\title{
Public Policies in Favelas and the Production of Urban Inequalities in Rio de Janeiro
}

\author{
Neiva Vieira Da Cunha
}

\section{INTRODUCTION}

n $\mathrm{n}$ the past three decades, we have witnessed the worldwide development of new economic dynamics that have intensified the most perverse and harmful effects of globalization processes. The global economy has increasingly produced intense social vulnerability and has driven a large number of people out of the center of the economic and social order (Sassen, 2016). This economic model responds to a logic of financialization of all domains of social life, imposed by different political choices and decisions that result in the degradation of working conditions and the increase of precariousness and insecurity throughout the world (Harvey, 1985). These consequences are not new and have already been described and analyzed by authors such as Serge Paugam (1991), Robert Castel (1995), and Didier Fassin (1996), among others. However, as Saskia Sassen (2016) points out, in a broader sense, this logic of financialization and production of new inequalities underway in the contemporary world can be seen as a more profound systemic underlying tendency that articulates realities that unite us. They often seem disconnected, and their modes of action, which can be characterized by their complexity, may include different dynamics and even coexist with economic growth. These dynamics may, for example, be produced by new technologies or technical devices, as well as by specialized knowledge, the impacts of which have caused a new order of accelerations and disruptions in the process of economic globalization (Sassen, 2016).

National states are directly involved in these processes and, in most cases, are even at the origin of these new dynamics of inequality production. It is in this context that we can address a new way of governing populations. In recent decades, governments could have used the development of the global economy and its capacity for capital creation to integrate the most vulnerable social groups and increase the welfare of societies. Yet, as the imperatives of the financial system have guided public policies, State action has served, above all, to tear the social fabric by producing extreme inequality and increasingly complicated ways to govern

Author: Professor at the State University of Rio de Janeiro/UERJ, Researcher at the Centre d'Études des Mouvements Sociaux/CEMSEHESS, Researcher at the Metropolitan Ethnography Laboratory/ LeMetro/IFCS-UFRJ, Researcher at the Institute of Comparative Studies in Conflict Management/INCT/In EAC-UFF.

e-mail: neivavieiradacunha@gmail.com populations. One of the areas that most highlights the variety of these new dynamics in several nations is the area of public policies for urban renewal and mass housing. From this point of view, analyzing the production of space (Lefebvre, 1974) of contemporary cities makes it possible to highlight the connections between this financialization process and the spread of neoliberal urban planning, owing to the entry of international capital into the real estate market, the privatization of public services, and the growing number of public-private partnerships in the implementation of urban policies. Authors such as David Harvey (1985, 2003, 2005), Neil Brenner \& Nick Theodore (2002), Raquel Rolnik (2015), Saskia Sassen (2016), among others, have already delved into the participation of finance capital in the production of contemporary cities. Especially since the late 1970s, this financialization process, understood here as "the growing influence of financial markets over the unfolding of economy, polity and society" (French et al., 2011, p.798), has had an increasingly active participation in transforming the production of space and in creating new urban inequalities, seeing that urban land appreciation and real estate speculation put into practice one of thetenetsof the financialization process, the production of wealth through the valuation of financial assets (Halbert, 2013, p.1).

From this perspective, Rio de Janeiro can be considered a symbolic case to think about the relations that may exist between public policies and the production of space and social inequalities. Rio's longterm urban development may thus reveal some peculiarities about the ways of governing impoverished populations and socio-spatial segregation in Brazil and Latin America, since the production of its space has always reaffirmed the idea of a market-oriented city, to the detriment of citizens' rights (Cunha, Carmam \& Segura, 2013). Throughout Rio de Janeiro's urban history, many experiences in terms of public housing policies and urban renewal projects have contributed to expelling the poor from the most valued areas of the city. These populations were somewhat expelled from the civitas, that is, the political city (Cunha \& Mello, $2011,2012)$. Among the public policies implemented in the city's favelas, those that have become known as favela removal policies, or favela policies, have had dramatic consequences on the lives of its inhabitants and, in the long run, on the very definition of the urban 
morphology of Rio de Janeiro and its metropolitan area. Its multiple effects have left deep marks on the collective memory and the trajectory of the various social groups subjected to this forced removal (Brum, 2012; Cunha \& Mello, 2012).

This article aims to analyze, through a retrospective ethnography (Burke, 1987; Cunha, 2005; Bezerra, 2015), the processes of implementation of these public policies in favelas, in their various forms and contexts, as well as their consequences, in terms of urban inequality production and socio-spatial segregation methods in the city of Rio de Janeiro. The analysis presented here was based on ethnographic research carried out in Rio de Janeiro's favelas, particularly the Santa Marta and the Chapéu MangueiraBabilônia favelas, where I was conducting fieldwork when the government implemented the favela pacification policy in 2008, in preparation for hosting international sport mega-events, such as the 2014 World Cup and the 2016 Summer Olympics. However, to understand what was happening in these territories, from the narratives of the dwellers and the categories they used at that time, and to talk about their lived experiences in terms of public policies, it was necessary to refer to past scenarios, events, and characters. Understanding ethnography as a work of complex textual construction, this perspective seeks to restore the dialogue between anthropology and history, inscribing diachrony and synchrony as complementary dimensions of the socio-anthropological enterprise (Bezerra, 2015). At first, I will present the socio-historical reconstruction of this public policy implementation process in Rio's favelas. This reconstitution was put together by listening carefully to the lived experience accounts and the collective memory of favela dwellers. Next, I will present the context for the recent implementation of favela pacification policies. The direct observation of the effects of these policies on the dwellers' daily lives informed this section. Finally, I will highlight the relation between (1) the process of producing favela representations and social classifications and (2) the broader process of production of space in Rio de Janeiro through the implementation of public policies for urban renewal and mass housing. My objective is to analyze the long-term effects of these public policies in terms of the restructuring of the urban space and the production of social inequalities owing to the expulsion of the most impoverished populations from the most valued areas of the city.

\section{Public Policies for Urban Renewal in the Early Twentieth Century}

Even before the emergence of the favelas in late $19^{\text {th }}$ century Rio de Janeiro, there were tenements, which were the main form of housing for the masses. These tenements were in fact old downtown buildings that were transformed by their owners into several dwellings and rented to poor people (Rocha \& Carvalho, 1995; Gonçalves, 2010). The development of this type of mass housing in downtown Rio de Janeiro dates to the second half of the $19^{\text {th }}$ century. The government have always deemed tenements unhealthy places, sources of disease and addiction, hideouts for criminals, and a constant threat to the social order (Chalhoub, 1996). This situation was reinforced in the late $19^{\text {th }}$ century with the emergence of the favela (a slum, or a shantytown), where impoverished workers and freed slaves settled ${ }^{1}$, particularly after the destruction of the tenements. For the powers that be, this population belonged to the dangerous classes (Chevalier, 1958) and, as such, should be far removed from the central and most affluent areas of the city (Cunha \& Mello, 2011). From the public authorities' perspective, this classification concerned not only health threats but, above all, the dangers this population posed to public order. Like the tenements, the favelas began to represent not only the risk of contagion and spread of diseases and epidemics, owing to their precarious and unhealthy housing conditions, but also a risk of moral contamination. Thus, the State measures to combat the tenements and the first favelas during this period were based on a social hygiene ideology and aimed to control the central space of the city, expelling the poor and working classes and freeing up land for the real estate market (Benchimol, 1990; Chalhoub, 1996; Cunha, 2005).

In this early $20^{\text {th }}$ century context, Rio saw the implementation of its first major urban renewal project. Many countries implemented the so-called urban renewal policies characterized by the demolition and reconstruction of housing units in working-class neighborhoods at different times in history (Déboulet \& Lelévrier, 2014). In the city of Rio, this initiative was the work of Mayor Pereira Passos, an engineer with a degree from the Ecole de Mines of Paris who, in 1902, implemented a vast urban renewal and sanitation program in the then capital city of the Republic of Brazil $^{2}$. Pereira Passos, nicknamed the tropical Haussmann ${ }^{3}$, vigorously focused his actions on the destruction of tenements, starting a campaign called the tear-down with the aim to "sanitize" and "civilize" the city, eradicating this type of housing and everything it

\footnotetext{
${ }^{1}$ The end of slavery in 1888 brought about the proliferation of not only slums but also tenements. According to official figures, the population living in tenements in 1869 amounted to 21,929 people and in 1888 to 46,680 people (Lobo \& Stanley, 1989; Gonçalves 2010).

${ }^{2}$ Aiming to integrate urban reform and health reform, Pereira Passos invited bacteriologist and epidemiologist Oswaldo Cruz, who had a degree from the Pasteur Institute in Paris, to join him.

${ }^{3}$ Georges-Eugène Haussmann, chosen by Napoleon III as prefect of the Seine in 1853, was responsible for the large urban renovation that "modernized" Paris; his public works became a historical reference point for urban planning.
} 
represented (Benchimol, 1990). In addition to tackling health issues, these public policies sought to legitimize a set of extremely authoritarian decisions on urban restructuring in Rio de Janeiro, producing significant socio-spatial segregation (Cunha, Carmam \& Segura, 2013). This first major urban renewal in Rio de Janeiro led to the destruction of 1,681 buildings and the eviction of around 20,000 people, triggering a demolition and reconstruction movement that ushered in the development of the real estate market (Vaz, 1988; Rocha \& Carvalho, 1995).

As a result of these actions, the occupation of hills and the expansion of favelas became a public problem (Dewey, 2010; Cefai, 2017a, 2017b). Under the influence of representatives of Rio's political elite, who played the role of moral entrepreneurs (Becker, 1985; Ogien, 2012) of hygienism, the diagnosis initially made for the tenements was extended to the favelas, which were also classified as a contagious evil and a social pathology that society must eradicate (Valladares, 2005). From this perspective, a notion of lack or absence have always characterized favelas, not only from the standpoint of infrastructure and public services (such as piped water, electricity, sewage services, waste disposal, etc.) but also from the moral point of view, as the government deemed them territory without order, without rules, and full of promiscuity (Chalhoub, 1996; Silva, 2004). Thus, since the early decades of the $20^{\text {th }}$ century, public policy proposals for "eradicating" favelas have often been formulated.

Throughout the 1920s, favelas expanded considerably. By this time, a new concept of urbanism was beginning to take shape beyond the policies inspired by the hygienist ideology. Under this new concept, which championed the notions of modernity, efficiency, and aesthetics in the production of urban space, favelas were deviant spaces. The fundamental assumption behind this classification of the favela was the idea that this type of dwelling space was a form of urban occupation that was contrary to the rationalist principles of city organization and development enforced by the government (Rocha \& Carvalho, 1995; Cunha \& Mello, 2012). Guided by this new paradigm of urban planning and modernization, French architect Alfred Agache, the urban planner in Mayor Prado Junior's administration, prepared the Plan of Extension, Renovation, and Beautification of the City of Rio de Janeiro, aimed at restructuring the city based on functional and space hierarchy criteria (Agache, 1930). This plan included the building of mass housing on the outskirts of Rio and deemed the eradication of favelas fully justified.

In 1937, the Rio de Janeiro City Hall approved a new Building Code to guide urban public policies until the 1970s. The text gave special attention to mass housing and, according to Gonçalves (2010), was the first legal document introducing the favela category into urban legislation. However, it did so in the form of a double ban: it prohibited the creation of new favelas while preventing any improvement of existing dwellings in these spaces. Thus, the Code adopted the same strategy previously used for the tenements, preventing any maintenance or renovation work so that the property would reach such a degree of degradation that its destruction would be the only possible solution. At the same time, it allowed the construction of new shacks on the hills on the outskirts of the city. This way, legislation limited the creation of new favelas without entirely banning them. This ambiguous form of recognition through tolerance (Gonçalves, 2010) eventually consolidated this kind of mass housing and led many landowners to file lawsuits to reclaim the land then occupied by favelas.

\section{a) Favela eradication policies and resistance from residents}

Although the idea of eradicating forms of mass housing emerged in the early $20^{\text {th }}$ century with Pereira Passos's urban renovation, the government effectively implemented these public policies in favelas only from the 1940s on (Valladares, 2005). They initiated with the so-called Proletarian Parks model and were later developed with the building of Provisional Housing Centers (CHP) and finally of large housing projects on the outskirts of the city, which received the residents of the largest favelas in Rio's more affluent South Zone ${ }^{4}$. The Proletarian Parks would temporarily house the people expelled from some favelas under the justification that these would undergo renovation (Burgos, 1998; Valladares, 2005). Between 1942 and 1944, the destruction of four favelas in Rio's South Zone brought 8,000 people to three Proletarian Parks. However, the promised renovation never happened, and the Proletarian Parks eventually became new favelas ${ }^{5}$ (Burgos, 1998; Gonçalves, 2010). This public policy also had a "civilizing" character and aimed to convert favela dwellers to a new way of life, integrating them into the formal city through their segregation. It exercised an extremely authoritarian social control of this population not only regarding how to use and maintain the housing units, but also regarding local sociability and movement of residents (Burgos, 1998; Brum, 2012). Also, favela dwellers were politically framed to secure support for the government. These public policies anticipated urban scenarios that would later materialize, but their restrictive nature eventually provoked a strong reaction from the residents, who began to form Resident Associations,

\footnotetext{
${ }^{4}$ The residents of Ilha das Dragas, Morro do Pasmado, Praia do Pinto, Morro da Catacumba, and Favela do Esqueleto were expelled from their homes and removed to housing projects such as Cidade de Deus, Cidade Alta, Vila Paciência, Vila Aliança, Vila Esperança, Vila Kennedy, among others.

${ }^{5}$ The government finally eradicated these new favelas in the 1960s.
} 
especially when new favela removals were announced (Leeds, 1978; Valladares, 2005; Silva, 2005).

In the late 1940s and early 1950s, moral entrepreneurs(Becker, 1985; Ogien, 2012) stepped up the public campaign against shantytowns ${ }^{6}$. This campaign was called "The Battle of Rio" and advocated the implementation of partnerships between public and private institutions to solve once and for all the favela problem (Silva, 2005). The economic interests of real estate developers and the government converged to promote the re-appropriation of urban space in Rio de Janeiro. In 1948, the Rio de Janeiro City Hall conducted the first favela population census, which demonstrated that favelas represented $7 \%$ of the city's total population. The data also legitimized the public policy proposal to "eradicate favelas" or at least "prevent their further development" (Prefeitura do Distrito Federal, 1949). It is in this context that the residents of the Borel favela, with the help of lawyer Antoine de Margarino Torres, created the Union of Favela Workers(UTF) in 1954 (Lobo \& Stanley, 1989). In addition to defending favela dwellers against evictions and removals, this association focused on land issues and played a critical role in mobilizing and promoting the collective action and resistance of favela dwellers (Gonçalves, 2010; Cefai, 2007).

At last, from 1962 to 1974, the favela removal policies took shape and were implemented. During successive administrations of Governors Carlos Lacerda, Negrão de Lima, and Chagas Freitas, the city of Rio de Janeiro suppressed 80 favelas, and about 140,000 residents were expelled from their homes and forced to live in housing projects on the outskirts of the city. According to Lícia Valladares (2005, p. 133), this was the most important public intervention against the favelas that Rio de Janeiro has ever known. It was the beginning of the Military Regime ${ }^{7}$, and an agreement between the Brazilian State and the US Agency for International Development (USAID) made it possible to obtain the necessary resources to finance the favela eradication policy through the building of large housing projects. Thus the real estate development sector benefited the most from these actions.

Consequently, the disturbance imposed by a rationalist and authoritarian planning model, supported by the violent actions of the State apparatus, would profoundly mark the living conditions of a large number of impoverished people in Rio. These policies imposed forced residential mobility on some of the inhabitants of a city already deeply marked by urban inequalities (Cunha \& Mello, 2012). The permanent postulate of these actions was that the poor belonged to the

\footnotetext{
${ }^{6}$ Journalist Carlos Lacerda launched this campaign with a series of articles about Rio's favelas published in 1948 by the Correio da Manhã newspaper. For more information, see Silva, M.L. (2005).

${ }^{7}$ In 1960, the city of Rio de Janeiro underwent significant institutional changes after the transfer of the capital to Brasilia. And in 1964, Brazil suffered a military coup that established a dictatorship for 20 years.
}

margins, to the outskirts of the city. It did not matter that these were areas where infrastructure and public services were virtually nonexistent. Thus, these public policies were not meant to improve these population's living conditions or plan a less unequal and unfair urban space. On the contrary, they were conceived as segregation policies aimed at expelling poor residents from the central areas of the city (Cunha, Carmam \& Segura, 2013).

All these operations, in terms of public policy, ultimately reinforced favela dwellers' resistance against these forced removal policies, prompting countless favela resident associations to meet in 1963 and create the Federation of Favela Associations of the State of Guanabara (FAFEG) ${ }^{8}$, which called for legal recognition of these working-class housing spaces and access to public services. During the 1960s and 1970s, FAFEG defended the right of dwellers to stay in the favelas and sought their active participation in cooperative infrastructure improvement works (Bisilliat, 1995; Valladares, 2005). Yet, the response of the military dictatorship to this resistance and the favela upgrading proposals was immediate. With the dictatorship, the federal government resumed the eradication policies and decided to directly coordinate actions in Rio's favelas, aiming to free up increasingly valued and coveted land for the real estate market. The Metropolitan Area Housing for Social Interest Administration (CHISAM) was then created to plan and implement this program. In this scenario, the military regime outlawed favela social movements and arrested some of their main leaders on charges of communism (Lobo \& Stanley, 1989; Gonçalves, 2010).

\section{b) Praia do Pinto: the paradigm for the favela eradication policies \\ Despite their resistance, favela dwellers were} unable to avoid the pressure of combined economic and political forces or the violent methods employed by the government. Among the shanty towns the government eradicated during this period, the case of the Praia do Pinto favela is symptomatic. Located between the Rodrigo de Freitas Lake and the Leblon neighborhoods, highly affluent areas in Rio's South Zone, it was the priority target of the favela eradication program. In 1969, a fire, the causes of which were never explained, destroyed it, reducing its $105,000 \mathrm{~m}^{2}$ to ashes (Burgos, 1998; Brum, 2012). The fire occurred at a time of tension between the favela dwellers, who were mobilizing to face the threat of expulsion, and the repressive military government, which accused and imprisoned several favela community leaders. This tragic episode forced the Praia do Pinto residents to leave the land occupied by the favela where residential

\footnotetext{
${ }^{8}$ In 1974 , with the merge of the State of Guanabara into the State of Rio de Janeiro, FAFEG became FAFERJ.
} 
buildings would be later built for the middle class. Some residents were relocated to housing projects, such as Cidade Alta and Vila Paciência, and others were moved to the Provisional Housing Center (CHP), all situated on the outskirts of the city (Brum, 2012). A few years later, this CHP originated the Maré favela, today considered one of the largest slums in the city of Rio, housing about 140,000 residents. Finally, there maining Praia do Pinto residents relocated to Cidade de Deus, in Rio's West Zone, giving rise to a new favela, which today houses about 50,000 people, according to the 2010 Population Census conducted by the Brazilian Institute of Geography and Statistics (IBGE).

Resident removal operations in the Praia do Pinto favela were carried out by CHISAM agents, who contacted the representatives of resident associations to let them know that dwellers were supposed to leave their homes, as their shacks would be destroyed. On the eviction day, CHISAM officers arrived accompanied by social workers of the Department of Social Work, the Army, and the Military Police (PM) (Gonçalves, 2010; Brum, 2012). The massive police presence thus prevented any possible resistance from the residents. Then the public agents occupied the houses and immediately cut off the supply of electricity and water so that residents would not reoccupy their homes. Finally, the Urban Cleaning Company (COMLURB) was responsible for moving the dwellers to the housing projects, freeing up the land for new uses. The participation of COMLURB is very symbolic, because it was an actual urban cleaning that segregated and excluded the poor from the city's most affluent areas, highly coveted by real estate developers. However, this removal policy eventually caused a significant population increase in favelas that were still standing. Since most of the housing projects receiving residents from Praia do Pinto and other South Zone favelas were about 50 kilometers (31 miles) away from their previous dwellings, some of the evicted residents would not live there. As they did not want to move away from their workplaces or where they had lived almost all their lives and built their social networks, many people resold their new houses and returned to favelas (Valladares, 1978) ${ }^{9}$.

\section{c) Growing violence in favelas and the pacification policies}

Since the 1980s, with the interruption of the implementation of the so-called removal policies that characterized the 1960s and 1970s, there has been a relative decrease in State interventionism in shantytowns. During the 1980s, the expansion of drug trafficking made government intervention even more complicated in these spaces, which began to be

\footnotetext{
${ }^{9}$ The policy offered the chance to purchase a housing unit, not social rent.
}

identified as "places of crime and violence"10. Particularly in the late 1980s, the "war on drugs" policy that guided government actions in favelas further increased violence in these territories. Far from offering an answer to the problem, this repressive model backfired and triggered increasingly strong reactions from drug trafficking groups, leading to disastrous consequences for slumd wellers (Silva, 1998; Cunha, 2004; Cunha \& Mello, 2011). The result of this war was an environment of insecurity and fear that eventually spread to the whole city. It was in this context that the municipal government implemented the Favela-Bairro Program in 1993. This program marked a change of perspective on the public policies implemented in favelas and, according to the formulators, intended to provide these places with public services and infrastructure (Leitão \& Delecave, 2015; Freire, 2015). The notion of resident removal was, for the first time in the history of public policies for favelas, excluded, and the program aimed to reduce the social distance between the shantytown and the formal city by treating these mass housing spaces as neighborhoods, even though it ended up imposing an urban model and way of life that disregarded favela dwellers' experiences in these territories. However, increased violence owing to the "war on drugs" policy became an obstacle to achieving the goals set by the Favela-Bairro Program (Leitão \& Delecave, 2015; Cunha \& Mello, 2012).

More recently, the choice of the city of Rio de Janeiro to host the 2014 FIFA World Cup and the 2016 Summer Olympic Games brought forth a series of public policy proposals to prepare the city for these international sports mega-events. Most projects focused on urban areas that the government considered strategic on account of their economic and tourism potential. Most interventions targeted mass housing areas, particularly shantytowns. In the complex negotiations between the government and the private sector aimed at securing the necessary investments to implement urban renewal projects, the issue of public safety was essential. Rio de Janeiro's rate of violence in recent decades, considered one of the highest in the world, made this issue a priority. Security thus became the prerequisite for the transformation and restoration of the urban areas concerned.

Therefore, in December 2008, the Rio de Janeiro State Secretariat of Public Security began the implementation of the Pacifying Police Units (UPP) in some favelas, which were occupied by a permanent police contingent that, according to the Secretariat, aimed to "control violent crime" and "recover areas "that

\footnotetext{
10 In the late 1970s, Comando Vermelho (Red Command), Rio de Janeiro's first large drug gang, was formed. During the 1990s, it split into two dissident factions: Amigos dos Amigos (Friends of Friends) and Terceiro Comando (Third Command). These factions fought each other for the control of drug trade in Rio, further increasing favela violence (Souza, 1996).
} 
were impoverished and dominated by drug traffickers ${ }^{11}$. The UPP implementation was immediately praised by the media, which rushed to boast the first results of pacification. Media outlets drew considerable attention to the supposed safe and calm mood that had settled over the pacified favelas (Cunha \& Mello, 2011). In practice, however, this public policy and the overt police presence were quickly questioned by residents and local observers, as this law enforcement institution resorted, once again, to violence and abuse of authority. Overall, the persistent lack of respect and consideration for favela dwellers was the most criticized issue. Unwarranted home invasions became a fully established practice, and residents continued to be treated as potential "thugs". Black youth suffered even more with social discrimination, which was further intensified by this public policy (Cunha, 2004). UPP's violent practices did not provoke any reaction from the authorities and were, in fact, another layer of police corruption, already practiced through extortion and selling of protection to drug dealers in the form of political merchandise (Misse, 1997). All these actions reinforced the feeling of mistrust and fear that favela dwellers have always felt towards the initiatives of the military police in these territories (Silva, 1998; Oliveira \& Carvalho, 1993; Cunha, 2004).

The Santa Marta favela was chosen for the implementation of the UPP pilot project ${ }^{12}$. This favela is located on a hill between the neighborhoods of Botafogo and Laranjeiras, at the heart of Rio's South $Z_{\text {Zone }}{ }^{13}$. Before the UPP implementation process, the Battalion of Special Operations (BOPE) ${ }^{14}$ occupied the favela. This strategy surprised even the residents, who, on November 20, 2008, came across a massive police presence for no reason. At first, they thought it was one of the regular PM actions in the favela, even though they were astonished at the large number of police officers there. Police presence intensified, and the population finally realized that the police was settling permanently in the favela. Thus, on December 19, 2008, a month after the BOPE arrived, the first UPP in the city was inaugurated under the command of then Captain Priscila Azevedo. It is worthy to note that Captain

\footnotetext{
${ }^{11}$ For more information, go to http://www.isp.rj.gov.br/Conteudo.asp? ident $=62$.

12 Between 2008 and 2014, UPPs were installed in favelas such as Cidade de Deus, Batam, Chapéu Mangueira/Babilônia, PavãoPavãozinho, Cantagalo, Tabajaras, Cabritos, Providência, Borel, Formiga, Andaraí, Turano, Macacos, among others. A total of 38 UPPs were installed by 2014.

${ }^{13}$ According to data from the Secretariat of Public Security, Santa Marta housed at the time 6,000 residents, distributed in a 54,692 $\mathrm{m}^{2}$ (approximately $588,700 \mathrm{ft}^{2}$ ) area. For updated data on UPP favelas from the Secretariat of Public Security, go to http://www.ispdados. rj.gov.br/UPP.html. However, it is noteworthy that there are discrepancies in the data on favela populations and areas published by different public agencies.

${ }^{14}$ The BOPE directly reports to the Special Operations Command of the Military Police of Rio de Janeiro State (PMERJ), which operates in Rio's favelas.
}

Azevedo attended the International Olympic Committee (IOC) meeting in Copenhagen in 2009, when Rio de Janeiro was chosen to host the 2016 Summer Olympics, as a way of ensuring the "pacification" of the city (Cunha \& Mello, 2011).

Since the installation of the UPP, the Santa Marta favela has become a model and laboratory for public safety policies. These were accompanied by several actions to gradually replace informal practices of access to public services, which were then regularized, allowing Light ${ }^{15}$, Rio's light and power company, to regain control of $90 \%$ of the electricity supply in the favela. This significantly affected the illegal "hotwire" practice that characterize favelas, as residents could no longer "hot-wire" the power supply to share their consumption or to avoid paying at all for the service. This procedure, widespread in Rio's favelas, can be considered as a form of infrapolitical resistance (Scott, 2009). According to James Scott (2009), this notion refers to practices that are not publicly announced, as law enforcement would repress them, so they are quietly suggested as a way to face and resist the precarious, neglected situation to which favela dwellers have always been subjected.

At the beginning of the regularization of public services in the favelas, a social rate was introduced to allow a reduction in the electricity bill for residents who had a Social Registration Number (NIS), as was the case of beneficiaries of the Bolsa Família Program. However, from 2011 on, all rates were standardized, and favela dwellers had to pay the same rates formal neighborhoods paid (Loretti \& Cunha, 2015; Pilo, 2015). Finally, after the favela had been mapped out, Light put up street nameplates and numbered the houses, providing residents with a city address for the first time. However, the electricity bill issued by the company was the only mail residents received directly at their homes (Cunha \& Mello, 2011). In addition to that, the control of housing maintenance works, which were now required to comply with regulations, caused building costs to increase considerably, making them often inaccessible to the favela dwellers. It also killed the so-called roof culture $^{16}$, as it was no longer possible to build home extensions according to the needs of the family, an essential strategy for the social reproduction of family groups in mass housing areas. This attempt to control more systematically these informal strategies to access public services and housing has led to numerous conflicts between favela dwellers and the government (Corrêa, 2012; Cunha \& Mello, 2012). According to the

\footnotetext{
15 Light settled in Rio de Janeiro in 1904 under the name of Rio de Janeiro Tramway, Light and Power Co.

${ }^{16}$ Roof culture is the habit of using the roof of one's home as a social space. As favela houses are usually small, the roof is a significant social space where many activities take place, such as parties, sunbathing, washing and drying clothes, etc. For more information, see Corrêa, 2012.
} 
residents, it has resulted in a significant increase in the cost of living in the favelas. Although they acknowledged that it was important to pay for urban services, they argued that the criteria for defining the rates were unclear and, above all, unfair. They maintained that slum dwellers, who lived in areas that still lacked basic services, infrastructure, and had open sewage and poorly lit streets, could not pay the same rate applied in the wealthiest neighborhoods of the city because the service quality was inconsistent (Loretti \& Cunha, 2015). Also, the creation of the UPP caused land and real estate prices to increase $400 \%$ in the favela and its vicinity, both for rent and purchase or sale. Finally, the residents mentioned a kind of white expulsion, due to the rising cost of living and real estate speculation (Cunha \& Mello, 2011; Sisternas \& Cunha, 2018).

\section{ili. Conclusion}

While the urban renewal policies implemented in Rio de Janeiro, particularly the so-called favela removal or eradication policies of the 1960s and 1970s, left deep marks on the city's collective memory, having evicted a high number of favela dwellers, the results of the pacification policies and urban renewal projects implemented to prepare the city for the 2014 World Cup and the 2016 Summer Olympics are even more dramatic $^{17}$. Whereas 20,000 people were displaced during the Pereira Passosad ministration and 30,000 during the Carlos Lacerdaad ministration, both of whom went down in history as mayors who had razed the city, the forced removal policies implemented by Mayor Eduardo Paes expelled 67,000 people; in most cases, they were relocated to places approximately $70 \mathrm{~km}(43.5$ miles) away from their former dwellings (Faulhaber \& Azevedo, 2016). Thus, throughout the urban history of Rio de Janeiro, we can say that the process of production of space through public policy implementation in favelas has always resulted in the expulsion of the most vulnerable social groups from the political city. These policies could have been an opportunity for the government to address Rio's urban inequalities; however, significant differences as to who has the right to the city (Lefebvre, 1968) persist and still characterize Rio de Janeiro.

Retrospective analysis of these policies shows that the logic behind these forms of expulsion changed over time. Initially, they were guided by hygienist ideology and aimed to control the central space of the city, removing the working classes and freeing up land for the promotion of the real estate market. These measures were meant primarily to cleanthe city's bad

\footnotetext{
${ }^{17}$ In addition to the favela pacification policies, the urban interventions that the government implemented to transform Rio into an Olympic city focused on renovating the port area, installing and renovating sports facilities, and providing urban mobility with the building of the Bus Rapid Transit (BRT)lines (Faulhaber \& Azevedo, 2016).
}

reputation as a dirty port or port of death and address the regular yellow fever epidemics that plagued Rio and destabilized its economy, hindering the development project of the government's elites. (Chalhoub, 1996, Cunha, 2005). Then, public policies addressed the claim that there was a need to reorganize the city based on functional criteria and stratification of urban space - a new concept of urbanism and urban planning. This new concept, influenced by the establishment of the real estate market, led to a hierarchical space division that further contributed to capital accumulation. Finally, when the government came to see favelas as the main threat to public safety and the city's image, pacification policies made it possible - in the context of cities as commodities - to implement new urban restructuring projects through the appreciation of urban land as a financial asset (Halbert, 2013, p.1). In this sense, this policy further improved the conditions that allowed the market to re-appropriate favela areas.

These different kinds of intervention implemented in Rio de Janeiro throughout its urban history fall into three ideal types, which correspond to three public policy models connected to different forms of favela representation and social classification: the hygienist model, which becomes a modernizing model and at last a public security model. We can say that different logics produced these models. If, when capital's appropriation of Rio's urban space first began, hygienist and modernizing policies aimed to stimulate the real estate market, which expanded significantly based on a new concept of urbanism and urban planning, then the pacification policies may be considered a consequence and escalation of this process of commodification of the city. It is an important distinction because the change was not just quantitative. In a scenario of financialization of the global economy, the expulsions of the most impoverished populations have not only increased considerably but also become much more intricate due to the financialization logic that promotes public-private partnerships in urban interventions and real estate speculation. It is worthy to underline that access to urban land and choice of place of residence remain fundamental issues for the poor populations of large metropolises in Brazil and Latin America. These people have always been segregated and forced to live in precarious spaces, and access to urban territory was only possible through the purchase of land on the outskirts of the city or through occupation, as was the case of the Rio de Janeiro favelas. Yet, in today's global economy, what is at stake is a new form of urban dispossession, as land value has become a key element in the process of financialization of cities (Rolnik, 2015; Sassen, 2016).

This way, we see that past and present public policies implemented in Rio's favelas are part of a logic of expulsion of the poor from a land that had an 
increase in value owing to the joint action of the State and the capital. These effects are becoming increasingly violent as public policies are now subject to financial profitability. Thus, we agree with Saskia Sassen (2016) that there is a systemic underlying tendency that makes the global economy confront us with a new logic of urban inequality production and with even more difficult, intense and aggressive ways of governing destitute populations. This new logic would be consistent with a new cycle of the global economy in terms of capital accumulation, including the process of financialization of cities. And, despite the resistance of some favela dwellers still struggling to stay in the most valued and sought-after areas of the city, the threat of expulsion remains a specter that perpetually haunts them.

\section{References Références Referencias}

1. Agache A.H.D., 1930, Cidade do Rio de Janeiro, Remodelação, Extensão e Embelezamento. Foyer Brésilien.

2. Becker H. S., 1985, Outsiders. Études de sociologie de ladéviance. Paris:Éditions Métaillé.

3. Benchimol J. L., 1990, Pereira Passos: um Haussmann tropical, Rio de Janeiro: Secretaria municipal de Cultura, Turismo e Esportes.

4. Bisilliat, J., 1995, La constructionpopulaireauBrésil. Une expérience à São Paulo. Paris: Editions Karthala et Orstom.

5. Brenner N. et Theodore N., 2002, "Citiesand the Geographies of Actually Existing Neoliberalism", Antipode, vol. 34, n⿳ 3, p. 349-379.

6. Brum M., 2012, Cidade Alta: histórias, memórias e estigma de favela num conjunto habitacional do Rio de Janeiro. Rio de Janeiro: Ponteio.

7. Burgos, M., 1998, Dos Parques Proletários ao Favela-Bairro, as políticas públicas nas favelas de Rio de Janeiro. In Zaluar, A. e Alvito, M. (Orgs.). Um século de Favela. Rio de Janeiro: FGV, 1998, p. 25-60.

8. Burke P., 1987, The HistoricalAnthropology of EarlyModernltaly. Essays in perception and communication. Cambridge: Cambridge University Press.

9. Carvalho, L. A., 1986, Contribuição aos estudos das habitações populares, 1886-1906, Rio de Janeiro: Secretaria Municipal de Cultura, Turismo e Esportes.

10. Castel R., 1995, Les Métamorphoses de laquestionsociale: une chroniquedusalariat. Paris: Fayard.

11. Cefai, D., 2007. Pourquoi se mobilise-t-on? Théories de l'actioncollective. Paris: La Découverte.

12. Cefai, D., 2017a. Públicos, Problemas Públicos, Arenas Públicas. O que nos ensina o Pragmatismo (parte 1). Novos Estudos, CEBRAP, São Paulo, vol.36 01, p. 187-213.

13. Cefai, D., 2017b. Públicos, Problemas Públicos, Arenas Públicas. O que nos ensina o Pragmatismo (parte 2). Novos Estudos, CEBRAP, São Paulo, vol. 36 02, p. 129-142.

14. Chalhoub S., 1996, Cidade Febril. Cortiços e epidemias na Corte Imperial. São Paulo: Companhia das Letras.

15. Chevalier, L. (1958). Classes laborieuses et classes dangereuses à Paris pendant la première moitiédu $X I X$. Paris: Plon.

16. Corrêa, C. (2012). Controvérsias. Entre o «direito à moradia” em favelas e o direito de propriedade imobiliária na cidade do Rio de Janeiro.Rio de Janeiro: Topbooks.

17. Cunha N.V., 2004, "Como se «fabrica» um policial: algumas considerações em torno dos processos de socialização e formação policial", Revista Comum, vol. 9, n²2, p. 198-207.

18. Cunha N.V., 2005, Viagem, Experiência e Memória. Narrativas de profissionais da Saúde Pública dos anos 30. Bauru, São Paulo: EDUSC-ANPOCS.

19. Cunha, N.V., Mello, M.A (2011) Novos conflitos na cidade: a UPP e o processo de urbanização na favela. Dilemas. Revista de Estudos de Conflito e Controle Social - Vol. 4 - n`3, 371-401.

20. Cunha N.V., Mello M., 2012, «A UPP e o processo de urbanização na favela Santa Marta: notas de campo ». InMello M., Freire L.L., Simões S.S., Machado, L.A., Favelas Cariocas ontem e hoje. Rio de Janeiro: Garamond-FAPERJ.

21. Cunha, N.V., Carmam, M., Segura, R., 2013(orgs.), Segregación y Diferencia en laCiudad. Equador: FLACSO-CLACSO.

22. Deboulet, A., Lelévrier, C., 2014 , Rénovationsurbaines en Europe. Rennes: PUR.

23. Dewey, J. 2010. Le publiques et sesproblèmes. Paris: Gallimard.

24. Fassin D., 1996, "Exclusion, underclass, marginalidad. Figures contemporaines de lapauvretéurbaine en France, aux États-Unis et en Amérique latine", Revuefrançaise de sociologie, vol. $37, n^{\circ} 1$, p. 37-75.

25. Faulhaber L., Azevedo L., 2016. Remoções no Rio de Janeiro Olímpico. Rio de Janeiro: Ed.Mórula.

26. Freire L.L., 2005, "Tecendo as redes do Programa Favela-Bairro em Acari", Dissertação de Mestrado em Psicologia Social, Universidade do Estado do Rio de Janeiro/UERJ.

27. French et al., 2011, "Financializing Space, Spacing Financialization", Progress in Human Geography, vol. 35, n 6, p. 798-819.

28. Gonçalves R., 2010, Les Favelas de Rio de Janeiro. Histoire et DroitXIXe et XXe siècles. Paris: L'Harmattan. 
29. Halbert L., 2013, "Les acteursdesmarchésfinanciers font-ils laville? Versun agenda de recherche", EspacesTemps.net.

30. Harvey D., 1985, The Urbanization of Capital. Oxford: Blackwell.

31. Harvey D., 2003, Paris, Capital of Modernity. New York: Routledge.

32. Leeds A. et Leeds E., 1978, A sociologia do Brasil Urbano. Rio de Janeiro: Zahar.

33. Leitão, G., Delecave, J., 2015. Favela-Bairro e Morar Carioca: reflexões sobre o que muda e o que permanece na política de urbanização das favelas da cidade do Rio de Janeiro, ao longo dos últimos 20 anos. In Pensando o Rio. Politicas publicas, Conflitos Urbanos e Modos de habitar. Kant de Lima, R., Mello, M.A.S., Freire, L.L., Niterói: EdUFF.

34. Lefebvre H., 1968, Le Droit à laville. Paris: Le Seuil, Points.

35. Lobo E. C., Stanley M., 1989. Questão habitacional e o movimento operário. Rio de Janeiro: Ed. UFRJ.

36. Loretti e Cunha, 2015. A eficiência energética na favela Santa Marta: usos e conflitos no espaço urbano. In Pensando o Rio. Politicas publicas, Conflitos Urbanos e Modos de habitar. Kant de Lima, R., Mello, M.A.S., Freire, L.L., Niterói: EdUFF.

37. Misse M., 2002. "O Rio como bazar. A conversão da ilegalidade em mercadoria política", Inteligência, vol. $3, n^{\circ} 5$, p. $12-16$.

38. Ogien, A. 2012. Sociologie de ladéviance. Paris: PUF.

39. Oliveira, A., Carvalho C., 1993.Favelas e as Organizações Comunitárias. Petrópolis: VozesCentro de Defesa dos Direitos Humanos Bento Rubião.

40. Paugam S., 1991, La Disqualificationsociale. Essaisurla nouvelle pauvreté. Paris: PUF.

41. Pereira M., 1996.A cidade planificada: o discurso dos médicos e a noção de interesse público entre o Império e a Republica: o caso do Rio de Janeiro, Comunicação apresentada no Seminário "Centenário da Republica".

42. Pilo, F., 2015. La régularisation des favelas parl'électricité. Unservisse entre État, marché et citoyenneté. Thèse en cotutelle Université Paris-Est (Aménagement de l'Espace, Urbanisme) et Universidade Federal Fluminense (Économie).

43. Prefeitura do Distrito Federal, 1949, Censo das Favelas. Aspectos Gerais. Rio de Janeiro: Departamento de Geografia e Estatística.

44. Rocha, O. P. et Carvalho, L. A., 1995, A era das demolições. Habitações populares. Rio de Janeiro: Secretaria Municipal de Cultura.

45. Rolnik, R., 2015. Guerra dos lugares: A colonização da terra e da moradia na era das finanças. São Paulo: Ed. Boitempo.
46. Sassen S., 2016 [2014], Expulsions. Brutalité et complexitédansl'économieglobale. Paris: Gallimard.

47. Scott J., 2008, La Domination et lesarts de larésistance. Paris:Éditions Amsterdam.

48. Silva J.S., 2004, "Favelas - Além dos estereótipos", Democracia Viva, $n^{\circ} 22$, p. 10-16.

49. Silva J., 1998, Violência e Racismo no Rio de Janeiro. Niterói: EdUFF.

50. Silva, M.L.P., 2005, Favelas Cariocas (1930-1964). Rio de Janeiro: Garamond.

51. Sisternas, J.T., Cunha, N.V., 2018. "De lapacificación a la touristification en una favela de Rio de Janeiro". In Milano, C.; Mansilla, J. (eds.) Ciudad de Vacaciones. Conflictos Urbanos en Espacios Turísticos, pp. 209-240. Barcelona: Editorial Pol-Em Ediciones, Spain,

52. Souza M.L., 1996, "As drogas e a «questão urbana » no Brasil: a dinâmica sócio-espacial nas cidades brasileiras sob a influencia do trafico de tóxicos", in Elias C. et al., Brasil: questões atuais da reorganização do território. Rio de Janeiro: Bertrand Brasil.

53. Valladares, L., 1978, Passa-se uma casa. Analise do Programa de Remoção de favelas no Rio de Janeiro. Rio de Janeiro: Zahar Ed.

54. Valladares L., 2005, Do mito de origem à favela.com. Rio de Janeiro: FGV Editora.

55. Vaz, L.F., 1988, "Do cortiço a favela, um lado obscuro da modernização do Rio de Janeiro", in Sampaio M.R.A. (org.), Habitação e Cidade. São Paulo: FAU/USP-FAPESP. 